\title{
At the Periphery of European Intellectual Space
}

\section{Nygård, Stefan}

Brill

2018

Nygård , S , Strang , J \& Jalava , M 2018 , At the Periphery of European Intellectual Space .

in S Nygård, M Jalava \& J Strang (eds), Decentering European Intellectual Space ., 1 ,

European Studies , vol. 35 , Brill , Leiden , pp. 1-15 . https://doi.org/10.1163/9789004364530_002

http://hdl.handle.net/10138/308621

https://doi.org/10.1163/9789004364530_002

acceptedVersion

Downloaded from Helda, University of Helsinki institutional repository.

This is an electronic reprint of the original article.

This reprint may differ from the original in pagination and typographic detail.

Please cite the original version. 


\section{THIS IS AN AUTHOR'S ORIGINAL MANUSCRIPT OF A CHAPTER IN THE BOOK DECENTERING EUROPEAN INTELLECTUAL SPACE, BRILL 2018 (EDS JALAVA, NYGÅRD \& STRANG)}

\section{At the Periphery of European Intellectual Space}

Stefan Nygård, Johan Strang, and Marja Jalava

European intellectual history has in the past two decades been enriched by excellent contributions from transnational or global perspectives. These studies have questioned the national paradigm and sketched an image of Europe as a complex interwoven intellectual space. ${ }^{1}$ Beyond the European context, the nature of intellectual transnationalism has been explored in pioneering inquiries of the planetary reach of, for instance, literature or the culture industry. ${ }^{2}$ These studies relate to the vast field of historical and social scientific scholarship that has emerged out of the sharp increase in border-crossing perspectives, cultural hybridity, and the circulation of people, ideas, and institutions.

Intended as a contribution to this growing literature, our volume asks whether intellectual historians, preoccupied with entanglement and hybridity, run the risk of painting an excessively harmonious picture of Europe as a cultural and intellectual space, reproducing the all too familiar image of a borderless space of texts and ideas where everyone is able to participate on equal grounds. Whereas studies on the geographies of knowledge production have convincingly shown that place, space, and their asymmetrical interrelations deserve careful consideration when assessing the socio-cultural conditions of intellectual life and the circulation of ideas, ${ }^{3}$ questions of spatiotemporal hierarchy have not been a major concern in the field of intellectual history. In general, European intellectual history or the history of intellectuals in Europe has focused primarily on relations and entanglements between the dominant nineteenth-century empires and nation-states such as France, Great Britain, Germany, or Russia. ${ }^{4}$ Less attention has been paid to the inevitable asymmetries of power that exist between big and small, center and periphery, core and margin,

\footnotetext{
${ }^{1}$ E.g., Christophe Charle, Jürgen Schriewer, and Peter Wagner, Transnational Intellectual Networks. Forms of Academic Knowledge and the Search for Cultural Identities (Frankfurt/New York: Campus Verlag, 2004); Gisèle Sapiro, L'espace intellectuel en Europe: De la formation des États-nations à la mondialisation, XIXe-XXIe siècle (Paris: Découverte, 2009); Darrin M. McMahon and Samuel Moyn (eds.), Rethinking Modern European Intellectual History (New York: Oxford University Press, 2014).

${ }^{2}$ Franco Moretti, Distant Reading (London: Verso, 2013); Pascale Casanova, La République mondiale des Lettres (2nd ed., Paris: Éditions du Seuil, 2008); Donald Sassoon, The Culture of the Europeans. From 1800 to the present (London: HarperPress, 2006); Samuel Moyn and Andrew Sartori, Global Intellectual History (New York: Columbia University Press, 2013).

${ }^{3}$ For an overview, see Kapil Raj, "Beyond Postcolonialism ... and Postpositivism. Circulation and the Global History of Science," Isis 104, no. 2 (June 2013); Kostas Gavroglu et al., "Science and Technology in the European Periphery: Some Theoretical Reflections," History of Science 46, Issue 2 (2008).

${ }^{4}$ Christophe Charle, Les intellectuels en Europe au XIXe siècle. Essai d'histoire comparée (Paris: Seuil, 1996).
} 
satellite and province - to name only some of the most frequently used terminologies for analyzing political, economic, or cultural hierarchies. ${ }^{5}$ This book is devoted to an examination of precisely such intra-European asymmetries. The aim is to reconsider the nature of European intellectual space and introduce into the debate analyses of the position and strategies of intellectuals, writers, artists, and scholars from non-dominant regions within Europe. If Europe in this period, roughly between the mid-nineteenth and the late twentieth centuries, was a global center of intellectual life and cultural production, what, then, was the role of its own internal peripheries?

\section{Intra-European and Colonial Relations}

The intra-European hierarchies studied in this book were conditioned by large-scale political developments such as the rise of competing forms of nationalism, colonial expansionism, social movements contesting the supremacy of the national state, the collapse of empires, the totalizing claims of the state between the world wars, and the rise of the bipolar Cold War constellation where Eastern Central Europe was suddenly provincialized, while Western Europe gradually lost its selfevident cultural centrality to the United States. Such macro-level developments had an important bearing on intellectual hierarchies, but it was never a one-to-one relationship. Sometimes the centers of European intellectual life overlapped geographically with military, political, or economic domination, and sometimes they did not. Moreover, insofar as the book is concerned with the extent to which space and location condition the strategies, outlook and self-understanding of individual and collective actors, we should recognize the specific role played by intellectuals in composing and contesting spatial constructions in the first place, including the notion of national territory. Having achieved some degree of hegemony, such spatial formations tend to take on a life of their own and determine the interaction between intellectuals and ideas, or the way historical actors position themselves in a larger whole.

Rather than systematically assessing the relationship between empirical reality and conceptual representations, the aim of this book is to explore the experience of being outside a dominant core and the strategies for acting that result from this experience. Perceptions of hierarchy shaped the behavior of intellectuals in the geo-cultural peripheries or "semi-peripheries," and gave rise to a whole spectrum of strategies for dealing with asymmetry, as demonstrated by the individual chapters in this volume. These strategies ranged from struggling for attention, translating modernity, imitating the centers, and stressing the need to catch up on the one hand, and contesting

\footnotetext{
${ }^{5}$ In European intellectual history, the "archetypal" asymmetry has been the one between Western and Eastern Europe; see Larry Wolff, Inventing Eastern Europe. The Map of Civilization on the Mind of the Enlightenment (Stanford, CA: Stanford University Press, 1994).
} 
or rejecting intellectual exports from the center and celebrating peripheral "authenticity" on the other hand. Sometimes the relation between geography, politics, and culture was articulated by mobilizing symbolic resources to compensate for geopolitical disadvantage. Typically, this has taken the form of marketing national cultural achievements and emphasizing culture over physical reality. ${ }^{6}$

The aptness of the terms "center" and "periphery" in describing intellectual relations has often been debated and criticized. Today, the conception of the periphery as a passive recipient of ideas developed in the core, or a provider of "raw materials" for the center, has been largely refuted. ${ }^{7}$ At the same time, the notions of "center" and "periphery" continue to raise strong emotions for and against. Some of the most important difficulties concern the units of analysis used for spatially defining a "center"-nation, city, region, specific institutions, etc.-and the "centralizing" and "peripheralizing" logics across social fields such as politics, the economy, science and higher education, and art and literature. Continuing this line of inquiry, as it pertains to the relations between intellectual spaces and their conceptualizations by writers, artists, and intellectuals, the contributions in the book suggest that speaking of centers in European intellectual space can refer to something spatial or temporal, and most often a mixture of both. "Europe" is no less ambiguous a term. ${ }^{8}$ In this volume, it relates both to the region, with its constantly negotiated borders, cores, and margins, and to the idea of Europe as the cradle of the Enlightenment and the beacon of modernity, with its claims to define the direction of universal progress and accompanying civilizing missions.

Drawing attention to multiple forms of structural and symbolic inequality, postcolonial studies has significantly contributed to disengaging us from a static center-periphery or "diffusionist" model of cultural interaction. Postcolonial studies has also been an important factor in a more general "spatial turn," highlighting place as being constantly produced and reproduced in interaction with its surroundings. In other words, places are not essences but processes, rooted in

\footnotetext{
${ }^{6}$ On the local level, culture has similarly been mobilized by national minorities to offset a political disadvantage, as in the case of Finland-Swedes in Helsinki or German speakers in Prague at the turn of the twentieth century.

${ }^{7}$ Peter Burke, History and Social Theory (Second Edition. Ithaca, NY: Cornell University Press, 2005), 82-87. See also Bruno Latour's discussion of scientific "centers of calculation" as a complex accumulation between places and networks of human and non-human resources, in Bruno Latour, Science in Action: How to Follow Scientists and Engineers through Society (Cambridge, Mass.: Harvard University Press, 1987).

${ }^{8}$ On the loose connection between center and spatial location, see Edward Shils, Center and Periphery. Essays in Macrosociology (Chicago \& London: University of Chicago Press, 1975). For a recent account of Europe in the world, see Bo Stråth and Peter Wagner, European Modernity. A Global Approach (London and New York: Bloomsbury Academic, 2017).
} 
social practices, disciplinary power, and ideology. ${ }^{9}$ But to what extent is it reasonable to apply theories addressing the inequalities of colonial or racial domination on intra-European conditions? One problem is the extent to which postcolonial studies targets Eurocentrism as a part of Western supremacy in the world. In their search for alternative de-centered visions, accounts inspired by dependency theory, postcolonialism, or subaltern studies have sometimes tended to flatten "Europe" into a single, monolithic entity, leaving out the asymmetrical relations and hegemonic struggles within Europe itself. To paraphrase Dipesh Chakrabarty, it is certainly true that scholars who study Europe are usually free to ignore or compartmentalize the experiences of Asians and Africans, but equally compartmentalized are the experiences of actors from peripheral, marginalized, or "backward" European regions. ${ }^{10}$

While postcolonial readings of intra-European asymmetries have inspired us to analyze forms of dependency and domination, it is a matter of debate how far we can carry the analogy. On the one hand, insofar as we are dealing with spatial asymmetries, one of the hypotheses of the book is, indeed, that the logic of combined and uneven development, in the language of world-systems theory, is more easily observable from the periphery, much in the same way as the dominance of Europe is most aptly seen from the outside. ${ }^{11}$ There are entanglements and structural similarities in terms of imperial dependency between the non-European colonies and the fringes of former European empires. To be sure, colonial history is an integrated part of the history of Europe that cannot be separated from the "internal" developments within the region. Moreover, colonial expansionism and colonial discourse impacted on how populations especially in frontier regions within Europe were perceived and treated, as pointed out by Roísín Healy and Enrico Dal Lago. Evidence of "discursive colonization"- - using colonial categories in framing relationships between self and other, often to justify the need to civilize the disadvantaged—can certainly be found within Europe itself. Sometimes these dichotomies, borrowed from a colonial setting and merged with the widespread scholarly and political racism of the nineteenth and early twentieth centuries, led to the subjugation of native populations by the colonizers. In other cases, the hierarchies were more discursive. ${ }^{12}$ Violent or discursive, they were expressions of world-ordering within a dominant paradigm of progress and modernity.

\footnotetext{
${ }^{9}$ Theoretically, the spatial turn is also indebted to such critical human geographers as David Harvey, Doreen Massey, and Edward Soja; see, e.g., Phil Hubbard and Rob Kitchin, eds., Key Thinkers on Space and Place (Second Edition. Thousand Oaks, CA: Sage, 2011).

${ }^{10}$ See the discussion in Frederick Cooper, Colonialism in Question. Theory, Knowledge, History (Berkeley: University of California Press, 2005), 20-32.

${ }^{11}$ See also the quote from Derek Walcott in Mikołajewski's contribution in this volume, which exemplifies this point.

${ }^{12}$ Roísín Healy and Enrico Dal Lago, "Investigating Colonialism within Europe," in The Shadow of Colonialism on Europe’s Modern Past, eds. Róisín Healy and Enrico Dal Lago (Basingstoke: Palgrave Macmillan, 2014), 4, 8-9.
} 
If the asymmetrical relations that such world-ordering produces are more tangible at the margins, this follows not necessarily from subjugation but from the fact that "latecomers" or culturally "underdeveloped" regions in the nineteenth and twentieth centuries had to make great efforts to insert themselves into an interconnected global system of nation-states. In doing so, peripheral intellectuals were faced with the power of universalizing discourse emanating from the centers, which they adapted, rejected, or transformed according to local demands. A specific problem for intellectual and cultural historians relates to the complexity of the multidirectional universe in which scientific, literary, and artistic practices are carried out, sometimes described as networks that connect a variety of urban and institutional nodes. The hierarchical dimensions of this universe translate into basic differences between, for example, those who can afford to universalize "local" experience and those who cannot. ${ }^{13}$

On the other hand, insofar as applying postcolonial discourse on intra-European developments means speaking of the European margins in the same breath as of former colonies, there is a risk of denigrating the suffering and the typically categorical outside position of the latter. After all, the European peripheries were in the period studied in this book predominantly considered "European" in the eyes of the centers, not as the "absolute Others of Europe." As such, they belonged to the group of "enlightened" and "civilized" cultures whose intellectuals, in principle, were entitled to participate in the discussion, although sometimes as "distant relatives," as the Polish exiled poet and essayist Czesław Miłosz suggests from his Polish-Lithuanian perspective: while they may have been acknowledged as Europeans, the peripheries were certainly not considered core "members of the family (quarrelsome but respectable)."14

Our volume thus contributes to previous research on Europe as seen from its geographical margins, including important works by Larry Wolff and Iver B. Neumann on Eastern Europe and Russia, Maria Todorova on the Balkans, Roberto Dainotto on Southern Europe, and Peter Davidson on "the North." ${ }^{15}$ Rather than focusing on a specific cardinal direction, however, we try to bring together experiences from a selection of "non-dominant" regions in Eastern, Western, Southern, and Northern Europe. The different Europes discussed here can be broadly divided into the centralimperial, the peripheral small states, and the "semi-central" former empires or intermediate countries such as Spain and Sweden. While some chapters look at Europe as an intellectual space

\footnotetext{
${ }^{13}$ See Stefan Nygård and Johan Strang, "Conceptual Universalisation and the Role of the Peripheries," Contributions to the History of Concepts 12, no. 1 (summer 2017): 57-77.

${ }^{14}$ Cited in Wolff, Inventing Eastern Europe, 373.

${ }^{15}$ Wolff, Inventing Eastern Europe; Maria Todorova, Imagining the Balkans (Oxford: Oxford University Press, 2009); Iver B. Neumann, Russia and the Idea of Europe: A Study in Identity and International Relations (London: Routledge, 1996); Roberto M. Dainotto, Europe (in Theory) (Durham, North Carolina: Duke University Press, 2006); Peter Davidson, The Idea of North (London: Reaktion Books, 2005).
} 
from its margins, others provide views from multicultural and multilingual contexts. Yet another group of articles assesses the role of asymmetry within intellectual networks or between intellectual fields. "Asymmetry" is in this context understood as an umbrella term for the mix of temporal and spatial hierarchies, for which historical actors (as well as analysts) have used a cluster of conceptual pairs such as center-periphery, core-margin, modern-backward, East-West, North-South, dominant-dominated, metropolis-satellite, or developed/developing-underdeveloped.

\section{Scales and Borders}

One way of dismantling the dichotomy of intra-European versus colonial hierarchies is to look beyond the framework of nation-states, which, despite the transnational turn in historical studies, continues to influence the way we structure our analyses. Moving beyond and across the boundaries of nation-states forces us to reconsider the question: where is the periphery? What kind of borders separate cores and margins? Should we follow the borders that separate nation-states and linguistic or cultural regions? Or should we break up these large-scale, ideological constructions into a more nuanced picture, take into account the existence of peripheries in the centers, centers in the peripheries, and perhaps shift attention from nationalized states to cities and urban centers, or even more specifically, to universities, publishing houses, or galleries, which after all constitute the main locus of intellectual life? ${ }^{16}$ And yet, as the historian Angelika Epple points out, the criticism of a narrowly national and/or state-centric framework does not necessarily mean that the historical significance of nation-states and the differences in local opportunity structures and cultures can be denied. Instead, the issue at stake is that there are multiple relations between different localities and actors, and the national scale is one of many possible spatial dimensions-but arguably, whether one likes it or not, an indispensable dimension when studying Europe in the nineteenth and twentieth centuries. In the period with which our volume is concerned, national(ized) discourses implied constraints that must neither be overlooked nor exaggerated. Hence, our objective is not to undermine nation-states; rather, we emphasize the degree to which such entities are never fixed, but fluid, relational, and historically changing. ${ }^{17}$

Regardless of which spatial scale we choose as our point of departure, however, we should acknowledge that centers and peripheries constitute each other in a mutually enforcing interaction, as this volume demonstrates with respect to non-dominant regions within Europe. There is also a

\footnotetext{
${ }^{16}$ Stefan Nygård and Blaise Wilfert-Portal, "Introduction," in The Geopolitics of Intellectual Space, eds. Stéphane van Damme, Stefan Nygård, and Blaise Wilfert-Portal (forthcoming 2018).

${ }^{17}$ See Angelika Epple, "The Global, the Transnational, and the Subaltern. The Limits of History beyond the National Paradigm," in Beyond Methodological Nationalism: Research Methodologies for Cross-Border Studies, ed. Anna Amelina et al. (New York: Routledge, 2012), 163-64, 168-70.
} 
striking similarity in terms of how such mechanisms work on different scales. The same kind of peripheral opposition to the provincial universalism of the self-sufficient core clearly characterizes twentieth-century relations between the Western and the non-Western world as well as the relations between dominant and non-dominant nation-states within Europe, but also between the centers and peripheries of any individual European country. Conversely, the uniformity of the center is often exaggerated when seen from the periphery, be it "Europe" in postcolonial studies, "France" or "Germany" from the viewpoint of non-dominant European countries, or urban centers from a rural or small-town perspective.

Different answers to the question of scale impact on how we describe trans-local relations within an inter-urban, inter-national, or cosmopolitan framework, which needs to be adjusted according to our different objects of study. The contributions in this volume focusing on European "peripheries" thus bring into the discussion a broad variety of scales and spatial dynamics. In most cases, the social field in which intellectual debates are situated transgresses national boundaries. Tensions between overlapping scales are mobilized in multiple ways by individual actors who draw on international references in order to strengthen the national, as in the nineteenth-century idea of a cosmopolitanism of nations, or conversely mobilize internationality in order to undermine locally dominant positions.

While remaining largely within the framework of European nation-states and urban centers, and paying close attention to their interconnections, the contributions in this volume seek to highlight the ways in which intellectuals, writers, and artists manoeuvre in the universe of national and imperial states competing with each other over political, economic, and cultural "progress." The book is both about elucidating how asymmetries are produced and about exploring how they determine the actions of individual and collective actors in the light of the different hierarchies. By reconsidering the premises for studying asymmetrical relations in European intellectual history, it aims at forging a perspective that avoids the tendency sometimes present in transnational intellectual history to overemphasize reciprocity and equality. The aim is also to coin a perspective which avoids the opposite tendency of fighting the injustice of a one-dimensional hierarchy sometimes associated with postcolonial discourse. Discussing examples from Northern, Eastern, and Southern Europe, the chapters analyze the ways in which historical actors in nineteenth- and twentieth-century Europe conceptualized intellectual space and how they dealt with its hierarchical aspects. By paying particular attention to the weaker part in asymmetrical relations, they highlight the extent to which perceptions of hierarchies defined the agendas of historical actors, how asymmetries were used, even instrumentalized, for strategic purposes at "home" and "abroad," how 
intellectuals managed tensions between local and transnational space, and how these spaces in themselves were produced and reproduced in continuous interaction with each other.

\section{The Structure of the Book}

The book is divided into three parts. The first part, Reconsidering European Intellectual Space, concerns the strategies of peripheral intellectuals around 1900. At that time, Western Europe with metropoles such as Paris, Vienna, Berlin, and London was widely acknowledged as the center of both European and global intellectual space. Although the period between the latter part of the nineteenth century and the First World War has been perceived as leading to the zenith of both global and intra-European interlinkages and structures, ${ }^{18}$ it was also a time when European intellectuals could still harbor a belief in European superiority. ${ }^{19}$ By and large, the production of national territory in the long nineteenth century - in part as a counterforce to turn-of-the-century globalization-resulted in the emergence of the nation-state in Europe as the dominant strategy for social organization, including intellectual life, although the idea of a borderless republic of letters also continued to be part of the self-understanding of intellectuals. As a result, for instance, literary, artistic, and academic markets only partly overlapped with national territories and borders. The chapters by Narve Fulsås \& Tore Rem and Stefan Nygård \& Johan Strang examine how these tensions and ambivalences impacted on the transnational strategies of Nordic small-country intellectuals with a strong self-proclaimed peripheral identity, whereas David Cottington's chapter examines the consolidation of a pan-European avant-garde network which contributed greatly to the decentering of Paris as the fulcrum of modernism. The field of avant-garde studies has shifted from a rigid image of international modernism with one undisputed center to a focus on decentered or at least multi-centered networks and to an understanding of notably cubism as "a language with many dialects." Other field-specific asymmetries are examined by Tommaso Giordani in his chapter on the interaction of German, Italian, and French Marxism, highlighting the interplay between two different intellectual fields: a Marxist European one dominated by Germany, and the national ones in France and Italy. Moreover, the chapter underlines variations in how the relation between the national and the transnational was conceptualized by actors from different contexts-in this case Italy, France, and Germany-as well as the obvious limits of center-periphery modelization for a field such as international Marxism

\footnotetext{
${ }^{18}$ See, e.g., Sebastian Conrad, Globalisation and the Nation in Imperial Germany, trans. Sorcha O'Hagan (Cambridge: Cambridge University Press, 2010), 29.

${ }^{19}$ For the simultaneous development of a global conscience and the new quality of European superiority, see, e.g., Matthias Middell and Katja Naumann, "The Writing of World History in Europe from the Middle of the Nineteenth Century to the Present: Conceptual Renewal and Challenge to National Histories," in Transnational Challenges to National History Writing, eds. Matthias Middell and Lluís Roura (Basingstoke: Palgrave Macmillan, 2013), 84-89.
} 
The second part of the book, Negotiating the Center, explores European intellectuals coping with dramatically transformed geo-cultural settings that were evident particularly after the First World War. The war brought along the collapse of the Romanov, Hohenzollern, Habsburg, and Ottoman Empires, ushering in an era of disorientation, lack of horizon, and identity crisis in Eastern and Central Europe, but it also led to new forms of international activities and concerns. The hierarchies examined by Diana Mishkova involve comprehensive perceptions and uses of asymmetry in the context of regional and civilizational discourse or national identity politics, the politics of belonging and demarcation with respect to imagined centers and significant others. In her contribution, Emila Palonen evokes the fluid nature of Europe as a center. She discusses the transnational trajectories of the Budapest School of Marxist humanism, drawing attention to the complex spatiality of a network spread across the globe in the cold-war period, from Melbourne to Moscow, at the same time as many of the key actors remained firmly anchored in European debates. The transformations of the twentieth century had significant implications for the developing world order, with the United States becoming the major challenger to the previously dominant Great Britain, France, and Germany, as discussed from a Spanish point of view in the chapter by José María Rosales. The defeat of Spain in the war with the USA in 1898, along with the loss of its colonial territories, was experienced by Spanish intellectuals as a negative decentering process, whereas the Nordic scholars, studied in the chapter by Marja Jalava \& Johanna RainioNiemi, seized upon the opportunities that were opened up by America's expanding cultural, academic, and economic influence on Europe. The latter chapter, in particular, emphasizes the flexibility of the peripheries in adjusting to such transformations, sometimes by playing centers against each other. One crucial aspect that sets the intellectual and academic fields of these countries apart is that while the question of dealing with geopolitical decline was a major concern for intellectuals such as Manuel Azaña and José Ortega y Gasset in Spain, as demonstrated by Rosales, Finnish and Norwegian intellectuals aspired to link their native cultural and scientific spaces to an emerging global academic center. With regard to old and new, progress and decline, these and other chapters reveal diverging combinations of spatial and temporal criteria for defining centrality, between accumulated cultural capital, position in global power-geometry, or promise for the future.

The final part, Cold War Dynamics, discusses the reconfiguration of European intellectual space after the Second World War. This space was solidified by an East-West division along the Iron Curtain, and yet, characterized by a constant blurring of the division and the ensuing fluctuation of center-periphery conceptions. In his chapter, Manolis Patiniotis examines the geopolitical tensions between centers and peripheries arising from cold-war national and 
transnational interests. He does this by exploring the Greek attempts to outline the dividing line so that the country would stay within the "free world," thus highlighting the role of the margins in the making of centers - Greece asserting its place as "the core of the center" - in twentieth-century transatlantic efforts to outline the borders of Western civilization. In Łukasz Mikołajewski's chapter, the focus is on Polish exiled authors who, with varied strategies and success, wanted to address both broader Western European audiences and readers in communist Poland at the same time. Finally, Zsófia Lóránd's chapter on Yugoslav feminism traces the asymmetries that emerged from the shifting ways in which Yugoslavia was seen in Europe before and after the break-up of the country in the early 1990s. The chapter not only highlights a meta-level asymmetry in terms of the still low number of women featured in intellectual history writing, but also raises the important issue of the non-simultaneity of political, economic, literary, and artistic geometries; when we, in the context of Yugoslav and Western feminism, pose the question of who was considered "advanced" and who needed "to catch up." The answer, of course, depends on the point of emphasis. For Yugoslavian feminists, gender relations may have appeared more advanced at home, but at the same time they saw themselves as lagging behind their Western colleagues in terms of freedom of expression and level of theorization.

Collectively, the book produces a multi-layered image of Europe by examining the relationships between intellectual spaces, fields, and markets of different size and status. The scale of analysis ranges from conceptualizing the place of nation-states and regions, in the chapter by Mishkova, to the field-specific asymmetries of Marxist theory or Yugoslav feminism examined by Giordani and Lóránd, respectively, and the global reach of the Budapest school of Hungarian intellectuals discussed by Palonen. Each contribution offers a different perspective on our general proposition to think "geometrically" about intellectual practices, by foregrounding asymmetries that operate on different levels and are to a varying degree acknowledged, contested, or challenged by the actors affected by them. While some of them dealt with geo-cultural asymmetry by mobilizing symbolic capital associated with a center in their own local setting, others sought to nuance the notion of advanced/backward, act as if the center-periphery dichotomies were meaningless, make use of them for personal gain, or to counterbalance a disadvantageous position by playing competing centers against each other. The key issue is that the perception or self-perception of geocultural position has been and still is a crucial factor in shaping how the individual actors navigate between the local, the national, the regional, and the transnational. It influences their understanding of how "external" events impact on "internal" developments, and their general level of interest in keeping up with, or opposing, developments elsewhere. 


\section{Europe through a Kaleidoscope}

Taken together, the chapters suggest that investigating Europe as an intellectual space is a kaleidoscopic exercise. Just as with each turn of the kaleidoscopic lens the pattern is significantly modified, European intellectual space naturally varies between points of observation. Moreover, it is constantly reproduced through negotiations that are more hierarchical and biased than they are reciprocal. The situatedness and the role of the local filter should always be considered when assessing conceptualizations of Europe as an intellectual space, whether they emanate from the core or the periphery. The book therefore stresses the need to look critically at the very logic of producing asymmetries, to recognize the importance of these dynamics for the self-understanding of individual actors with different horizons of expectations, to pay attention to individual actors' strategies for dealing with geo-cultural constraints, and to consider the extent to which asymmetries foster or even force actors into reflectivity and resistance vis-à-vis universalizing tendencies.

On the level of national space, the ideal-typical poles in the transnational process of negotiating cultural Europe are, on the one hand, small latecomer nations such as Finland in the Northern European context, where the actors are characterized by a predominantly peripheral selfunderstanding. Intellectuals belonging to this group were generally more inclined to instrumentalize "Europe" for specific local purposes than to try and participate in transnational discussions on equal grounds. Then we have the cultural centers, typically constituted by metropoles such as Paris, Berlin, and London in the nineteenth century, with a stronger tendency to universalize local debates, a tendency that was both contested and reinforced by the peripheries. And in between we find such countries as Sweden, Poland, Italy, Hungary, and Spain, where perceptions of geo-cultural position were fundamentally transformed or persistently ambivalent in the period discussed in this book.

In addition to diverse understandings of supranational space, closely connected with notions of time, progress, and modernity, different regions and competing factions within them tended to operate with different "Europes" to begin with. Indeed, the extent to which we can talk about a European intellectual space crucially depends on our acknowledging the intrinsic ambivalences of the concept, the porousness of "borders," the "internal peripheries" of core regions that are obscured when the nation-state is the dominant unit of analysis, and the importance of relations to trans-European spaces.

By focusing on conceptualizations other than those of the centers or of regions subjected to colonial domination in the twentieth century, the volume conveys not only the role of hierarchy but also the multi-directional transfers of ideas between "centers" and "peripheries," the crucial role of mediators, and the complex mechanisms by which asymmetries are produced and reproduced through the behavior and choices made by historical actors in dealing with structural constraints. 
While the world-systems perspective of combined and uneven development—and the claim that progress in one part of the world is matched by underdevelopment elsewhere-is not irrelevant for understanding how transnational intellectual space works, the chapters included in this book clearly illustrate the difficulties involved in reducing the role of the peripheries to recipients or producers of "raw material" to be processed by the centers.

Exploring different ways of studying intellectual asymmetries and investigating the power of perceptions of centrality and marginality are pertinent tasks for the study of modern European intellectual history today. While it has been a great merit of transnational history to recognize the integral part played by "foreign" references in the creation of national spaces, the passionate critique of methodological nationalism and the focus on hybridity has also served to obscure the hierarchical dimensions of, in our case, intra-European intellectual encounters. With its specific reference to intellectuals-writers, artists, historians, and social theorists - the book speaks to the long-standing debates on the tensions between, on the one hand, the idea of an egalitarian and supranational community of intellectuals, and, on the other hand, local rootedness, national, urban, or linguistic allegiances and discourses, and the symbolic power they continue to entail. ${ }^{20}$

\section{References}

Burke, Peter. History and Social Theory. Second Edition. Ithaca, NY: Cornell University Press, 2005.

Casanova, Pascale. La République mondiale des Lettres. Second Edition. Paris: Éditions du Seuil, 2008.

Charle, Christophe. Les intellectuels en Europe au XIXe siècle. Essai d'histoire compare. Paris: Seuil, 1996.

Charle, Christophe, Jürgen Schriewer, and Peter Wagner. Transnational Intellectual Networks. Forms of Academic Knowledge and the Search for Cultural Identities. Frankfurt and New York: Campus Verlag, 2004.

Conrad, Sebastian. Globalisation and the Nation in Imperial Germany. Translated by Sorcha O'Hagan. Cambridge: Cambridge University Press, 2010.

Cooper, Frederick. Colonialism in Question. Theory, Knowledge, History. Berkeley: University of California Press, 2005.

Dainotto, Roberto M. Europe (in Theory). Durham, North Carolina: Duke University Press, 2006.

\footnotetext{
${ }^{20}$ The book is the result of collective reflections on the hierarchical aspects of European intellectual space, conducted in a series of workshops with historians working on different parts of Europe and organized in Florence, Helsinki, Berlin, and Rome between 2013 and 2016. We are grateful to the Academy of Finland for making it possible for us to host these workshops. We would also like to thank the Department of History and Civilization at the European University in Florence and the Finnish institutes in Berlin and Rome for their hospitality.
} 
Damme, Stéphane van, Stefan Nygård, and Blaise Wilfert-Portal. The Geopolitics of Intellectual Space (forthcoming 2018).

Davidson, Peter. The Idea of North. London: Reaktion Books, 2005.

Epple, Angelika. "The Global, the Transnational, and the Subaltern. The Limits of History beyond the National Paradigm." In Beyond Methodological Nationalism: Research Methodologies for Cross-Border Studies, edited by Anna Amelina, Devrimsel Deniz Nergiz, Thomas Faist, and Nina Glick-Schiller, 155-75. New York: Routledge, 2012.

Gavroglu, Kostas, Manolis Patiniotis, Faidra Papanelopoulou, Ana Simões, Ana Carneiro, Maria Paula Diogo, José Ramón Bertomeu Sánchez, Antonio García Belmar, and Agustí Nieto-Galan. "Science and Technology in the European Periphery: Some Theoretical Reflections." History of Science 46, Issue 2 (2008): 153-75.

Healy, Roísín and Enrico Dal Lago. "Investigating Colonialism within Europe." In The Shadow of Colonialism on Europe's Modern Past, edited by Róisín Healy and Enrico Dal Lago, 3-22. Basingstoke: Palgrave Macmillan, 2014.

Healy, Róisín and Enrico Dal Lago, eds. The Shadow of Colonialism on Europe's Modern Past. Basingstoke: Palgrave Macmillan, 2014.

Hubbard, Phil and Rob Kitchin, eds. Key Thinkers on Space and Place. Second Edition. Thousand Oaks, CA: Sage, 2011.

Latour, Bruno. Science in Action: How to Follow Scientists and Engineers through Society. Cambridge, Mass.: Harvard University Press, 1987.

McMahon, Darrin M. and Samuel Moyn, eds. Rethinking Modern European Intellectual History. New York: Oxford University Press, 2014.

Middell, Matthias and Katja Naumann. "The Writing of World History in Europe from the Middle of the Nineteenth Century to the Present: Conceptual Renewal and Challenge to National Histories." In Transnational Challenges to National History Writing, edited by Matthias Middell and Lluís Roura, 54-139. Basingstoke: Palgrave Macmillan, 2013.

Moretti, Franco. Distant Reading. London: Verso, 2013.

Moyn, Samuel and Andrew Sartori. Global Intellectual History. New York: Columbia University Press, 2013.

Neumann, Iver B. Russia and the Idea of Europe: A Study in Identity and International Relations. London: Routledge, 1996.

Nygård, Stefan and Blaise Wilfert-Portal. "Introduction." In The Geopolitics of Intellectual Space, edited by Stéphane van Damme, Stefan Nygård and Blaise Wilfert-Portal (forthcoming 2018).

Nygård, Stefan and Johan Strang. "Conceptual Universalisation and the Role of the Peripheries," Contributions to the History of Concepts 12, no. 1 (summer 2017): 57-77.

Raj, Kapil. "Beyond Postcolonialism ... and Postpositivism. Circulation and the Global History of Science." Isis 104, no. 2 (June 2013): 337-47.

Sapiro, Gisèle. L'espace intellectuel en Europe: De la formation des États-nations à la mondialisation, XIXe-XXIe siècle. Paris: Découverte, 2009. 
Sassoon, Donald. The Culture of the Europeans. From 1800 to the Present. London: HarperPress, 2006.

Shils, Edward. Center and Periphery. Essays in Macrosociology. Chicago and London: University of Chicago Press, 1975.

Stråth, Bo and Peter Wagner. European Modernity. A Global Approach. London and New York: Bloomsbury Academic, 2017.

Todorova, Maria. Imagining the Balkans. Oxford: Oxford University Press, 2009.

Wolff, Larry. Inventing Eastern Europe. The Map of Civilization on the Mind of the Enlightenment. Stanford, CA: Stanford University Press, 1994. 